\title{
NATIONAL PARKS AND LOCAL DEVELOPMENT IN POLAND: A MUNICIPAL PERSPECTIVE
}

\author{
Bernadetta Zawilińska ${ }^{\mathrm{a}}$, Mirosław Mika ${ }^{\mathrm{b} *}$ \\ ${ }^{a}$ Cracow University of Economics, Department of Regional Economy, Poland \\ ${ }^{b}$ Jagiellonian University, Institute of Geography and Spatial Management, Poland
}

\begin{abstract}
The article is addressing the problem of local authorities seeing in national parks a stimulus or a barrier for local development in Poland. The results of surveys conducted among representatives of authorities of selected municipalities $(n=61)$, in which there are national park areas show that the assessment of the role and impact of this type of protected areas varies. In most cases the presence of national parks is viewed positively. Emphasis is put on their importance to the local socio-economic development. The economic benefit is seen mainly in the tourism sector and the development of associated services. However, local communities experience many restrictions resulting from functioning of protected areas, especially in regard to the possibility of increasing revenues to the budgets of municipalities, production entrepreneurship development and intensification of agricultural production and fisheries. It is believed that in the future parks should stimulate local development to a larger extent. To achieve this, it is necessary to see a national park as a system linked to the socio-economic environment and to take planning actions based on a holistic look at natural, social and economic issues of a national park and its neighbourhood. The cooperation between local authorities, parks' management, non-governmental organisations and local tourism business should be strengthened as well as steps should be taken in order to increase social participation in shaping the development of these areas.
\end{abstract}

Key words: Poland, National parks, Local development, Economic impact, Tourism development.

Article Info: Manuscript Received: November 27, 2012; Revised: April 2, 2013; Accepted: April 25, 2013; Online: May 25, 2013.

\section{Introduction}

Protected areas are established to preserve nature and its values but they do have an impact on social and economic environment (Fortin, Gagnon, 1999; Stolton, Dudley, 2010). The protective regime associated with the functioning of a protected area largely limits business opportunities, such as development of tourism, not only within the area, but also in its vicinity (Fortin, Gagnon, 1999; Getzner, 2003). Restrictions resulting from nature conservation priorities are often regarded by local communities as a barrier for local development and lead to conflicts. Social and economic benefits following the introduction of legal protection tend to be much less noticed.

From the perspective of local development,

\footnotetext{
* Corresponding author:

Address: Jagiellonian University, Institute of Geography and Spatial Management, 30-387 Cracow, 7 Gronostajowa St., Poland

Telephone: +48601936829

Email: mika@bb.onet.pl
}

presence of most valuable natural areas within the borders of a municipality should be an asset and benefit the local community. The advantages should be both tangible - the existence of a park should prompt economic development of the municipality and intangible - there should be a subjective feeling of high quality of life and benefits for health. The higher the income derived from a given protected area, the higher the level of social acceptance (Zawilińska, 2010). An indifferent or negative attitude towards the park will result in a lack of acceptance of the restrictions imposed by a given form of protection and in a lack of cooperation.

Working out mechanisms enabling an increase in benefits arising from protected areas requires first and foremost discernment of the role they play in the local socio-economic system (Pawlusiński, Mika, Faracik, 2008). Therefore, studies were undertaken to assess the impact of national parks on elements of social and economic life in involved municipalities and to define the character of mutual contacts between local authorities and the management of these protected areas. 


\section{The system of national parks in Poland}

The tradition of nature conservation in Poland goes back to the $14^{\text {th }}$ century. At present, the system of various forms of protected areas covers $32 \%$ of the total country area. Poland is at the European forefront in terms of the number of protected areas (9343 areas), the percentage of the total surface area covered by protected areas and the size of protected area per capita $\left(2655 \mathrm{~m}^{2}\right.$ per capita).

Various forms of natural protected areas can be found in $80 \%$ of all municipalities in Poland and for $25 \%$ of all municipalities, these areas account for over half their territory. Considering the importance of natural values, strict protective regime and their relatively large areas, national parks are, among all categories of protected areas, the most important for social and economic development in protected areas.

The beginnings of creating national parks in Poland date back to the 1930s. 23 national parks have been established in Poland so far ( 15 of them have II category according to IUCN), covering the total area

Table 1. National parks in Poland (year 2010) of $3144.74 \mathrm{~km}^{2}$ (table 1), which represents about $1 \%$ of the state territory. Protection in the form of national parks occurs in 119 communes, which belong to 48 districts and 12 provinces (in 2010). Compared with national parks worldwide, Polish national parks are relatively small in terms of their area; their average surface area is $137 \mathrm{~km}^{2}$. All parks have protection zones (buffer zones) of $4478.39 \mathrm{~km}^{2}$ in total.

National parks were established in all landscape zones of the country (table 1). They include the most valuable natural areas usually characterized by very high tourism attractiveness. Most national parks are located in sparsely populated and poorly developed remote areas. Only in some cases, national parks are located in close proximity to large urban areas (Kampinos NP in the outskirts of Warsaw and Wielkopolska NP in the vicinity of Poznan), or very popular tourist destinations (especially mountain national parks such as Tatra NP and Karkonosze NP, or the seaside national park - Wolin NP). The vast majority of communes with parks within their borders are of rural character. The biggest cities which have national parks within their administrative

\begin{tabular}{|c|c|c|c|c|}
\hline National park & $\begin{array}{c}\text { Year of } \\
\text { establishment }\end{array}$ & Area $\left[\mathrm{km}^{2}\right]$ & $\begin{array}{c}\text { Number of tourists } \\
\text { [thousands] }\end{array}$ & $\begin{array}{c}\text { Landscape } \\
\text { zones }\end{array}$ \\
\hline Słowiński NP & 1967 & 215.73 & 311.4 & \multirow{2}{*}{ seashores } \\
\hline Wolin NP & 1960 & 81.35 & 1500.0 & \\
\hline Bory Tucholskie NP & 1996 & 46.13 & 60.0 & \multirow{5}{*}{ lake districts } \\
\hline Drawa NP & 1990 & 113.42 & 22.2 & \\
\hline $\begin{array}{l}\text { Warta River Mouth } \\
\text { NP }\end{array}$ & 2001 & 80.74 & 10.0 & \\
\hline Wielkopolska NP & 1957 & 75.84 & 1200.0 & \\
\hline Wigry NP & 1989 & 149.81 & 110.0 & \\
\hline Białowieża NP & 1932 & 105.17 & 170.0 & lowlands \\
\hline Biebrza NP & 1993 & 592.23 & 31.0 & \\
\hline Kampinos NP & 1959 & 385.44 & 1000.0 & \\
\hline Narew NP & 1996 & 73.50 & 12.5 & \\
\hline Polesie NP & 1990 & 97.64 & 24.3 & \\
\hline Ojców NP & 1956 & 21.46 & 400.0 & \multirow{3}{*}{ uplands } \\
\hline Roztocze NP & 1974 & 84.83 & 100.0 & \\
\hline Świętokrzyski & 1950 & 76.26 & 145.0 & \\
\hline Babia Góra NP & 1954 & 33.91 & 54.0 & \multirow{9}{*}{ mountains } \\
\hline Bieszczady NP & 1973 & 291.95 & 280.0 & \\
\hline Gorce NP & 1981 & 70.31 & 60.0 & \\
\hline Table Mountains NP & 1993 & 63.40 & 319.0 & \\
\hline Karkonosze NP & 1959 & 55,81 & 2000.0 & \\
\hline Magura NP & 1995 & 194.38 & 50.0 & \\
\hline Pieniny NP & 1932 & 23.46 & 603.0 & \\
\hline Tatra NP & 1947 & 211.97 & 2002.0 & \\
\hline TOTAL & & 3144.74 & 10464.4 & \\
\hline
\end{tabular}

Source: Ochrona środowiska... (2011). 
borders are Jelenia Góra (84.6 thousand inhabitants) and Świnoujście (40.8 thousand). Average population density in communes administratively connected with parks is low, merely 58 persons $/ \mathrm{km}^{2}$. The lowest population density is in the Bieszczady NP communes: Lutowiska (5 persons $\left./ \mathrm{km}^{2}\right)$ and Cisna (6 persons $/ \mathrm{km}^{2}$ ). National parks are areas frequently visited by tourists. The highest number of visitors is noted in parks in the mountains, especially in Tatra NP and Karkonosze NP (about 2 million tourists per year in each), on the coast of the Baltic Sea and in suburban zones of big cities. Warta River Mouth National Park and Narew River National Park have the lowest numbers of tourists (table 1).

\section{Economic role of national parks}

The majority of research on functioning of national parks in Poland regards issues of the natural environment such as biodiversity and methods of protection. Much attention is also paid to the problem of anthropogenic impact, including the negative impact of tourism and tourist infrastructure on natural environment (i.a. Gorczyca, Krzemień, 2002; Jodłowski, 2011; Łajczak, Michalik, Witkowski, 1995; Mika, 2004; Partyka, 2002) as well as to the problems of management in parks, for example related with forestry, agriculture and tourism as their main economic functions (i.a. Bołtromiuk, 2001; Pawlusiński, Mika, Faracik, 2008; PtaszyckaJackowska, Baranowska-Janota, 1996).

No detailed research concerning economic importance of parks for their territorial surroundings has been conducted. Comprehensive research on the impact of protected areas on social and economic development of the areas located within their borders and in the neighbourhood has not yet been carried out in Poland. Among the few studies on the economic context of functioning of a national park, there is the study by Bottromiuk (2010), presenting Białowieża National Park as an employer, contractor, investor, service recipient and a property owner.

Few authors see the benefits and opportunities for development of areas located within or adjacent to protected areas in tourism, ecological agriculture and handicrafts (Konopka, 2001; Owsiak et al., 2001). Local governments and residents usually see the crucial role of national parks or landscape parks in promotional and educational activities, tourism development and activities for nature conservation (Osiniak et al., 1993; Zawilińska, 2010a; Zimniewicz, 2005). The well-preserved natural resources and landscapes, and operation of protected areas are also seen as an advantage for the development at provincial level, which is reflected in all Regional Development Strategies (Zawilińska, 2010b).
Creation of protected areas imposes a lot of restrictions on economic use of the area, which are often not accepted by local communities. Discrepancies between economic interests and nature conservation goals are reflected in numerous conflicts and protests of local residents against establishing new or extending existing national parks. Some of the protests, especially in relation to landscape parks, undoubtedly result from lack of knowledge of actual restrictions associated with the establishment of a park. However, it must be emphasized that in most cases, concerns of local communities are welljustified. Establishment of legal protection results in a partial loss of income generated by business development and in case of very strict protection forms also in other restrictions (e.g. for walking in the forest). These problems have been widely discussed in studies on the Białowieża Forest areas (Poskrobko, 1996) and Wigry National Park (Osiniak et al., 1993; Szkiruć, 2001). Restrictions and barriers in business development (including tourism) and the problem of unemployment in protected areas were also pointed out by Gotkiewicz (2001), Popławski (2005) and Szczepanowski (2007).

In an international literature, issues related to the impact of protected areas on social and economic development of the areas within their borders and in the vicinity are brought up more often. Ongoing studies present varied methodical approach (IUCN, 1998). Analyses of economic impact of tourismrelated arrivals to national parks, based on expenditures of tourists visiting these sites were carried out, among others, in Finland - in PallasOunastunturi National Park (Huhtala, 2007), in New Zealand - in Westland National Park (Pearce, 1981), in six German national parks (Meyer et al., 2010), in the USA - in national parks Mammoth Cave and Great Smokey Mountains (Stynes, Rutz, 1995; Stynes, 2002). In U.S. national parks, a model has been developed for measuring the impact of tourists' expenditures on local economy (Stynes et al., 2000).

Social and economic consequences of national parks' presence were analysed in the Republic of South Africa (i.a. Kruger, Addo, Karoo national parks) on the basis of surveys conducted among local communities, business entities and tourists (Saayman, Saayman, 2006a 2006b; Saayman, Saayman, Ferreira 2009). In Quebec in Canada, interviews with local leaders, as well as other data showed strong influence of national parks on local resource management, local economy, tourist industry, living conditions, quality of life, social mobilization (i.e. involvement and participation of local actors), social organization and dynamics, as well as environmental education with respect to sustainable development (Fortin, Gagnon, 1999). Studies aimed at estimating direct and indirect 
impact of tourists' expenditures and national parks managements' expenses on local economy (based on input - output analysis) have also been performed since 1998 in the Australian state New South Wales (Economic benefits of national parks and other reserves in New South Wales, 2009). In Austria, the economic impact of national parks in rural areas was determined on the basis of local governments' opinion poll (Getzner, 2003).

Research in the impact of national parks on local social and economic situation conducted in different countries pointed to the positive aspects of parks' functioning, manifesting mainly in the increase of jobs available, the development of tourism and depending industries and the emergence of new investments.

Getzner (2003) also notes that economic success of national parks' existence is largely dependent on planning and decision making processes, local and regional stakeholders' involvement, as well as on cooperation between local governments and national parks' managements. Many authors, among others Borrini-Feyerabend et al. (2004), Davey (1998), Dudley (2008), Fortin, Gagnon (1999), Phillips (2002), Plummer, Fennell (2009) draw attention to the necessity of implementing participatory approach, involving local communities in decision making processes related to the management of protected areas of various categories. In their studies, they recommend the model of co-managing protected areas, based on continuous cooperation between parks managements and local and regional authorities, residents, businesses and nongovernmental organizations.

Local communities should become part of park management scenario. Supporting local social and economic development should be included in the overall objectives of the protected area, and the conservation plans for the park should also include provisions for ensuring adequate benefits to local communities, resulting from the establishment of the protected area. As a result, the managements of protected areas should play an active role in supporting local development (Hamilton, McMillan, 2004; Mose, 2007).

\section{Research methodology}

The main sources of information were the results of surveys conducted in the offices of the municipalities connected administratively with national parks. The study included all municipalities in Poland, in which at least $10 \%$ of the area lies within the borders of a national park (total $\mathrm{n}=61$ municipalities) - figure 1 .

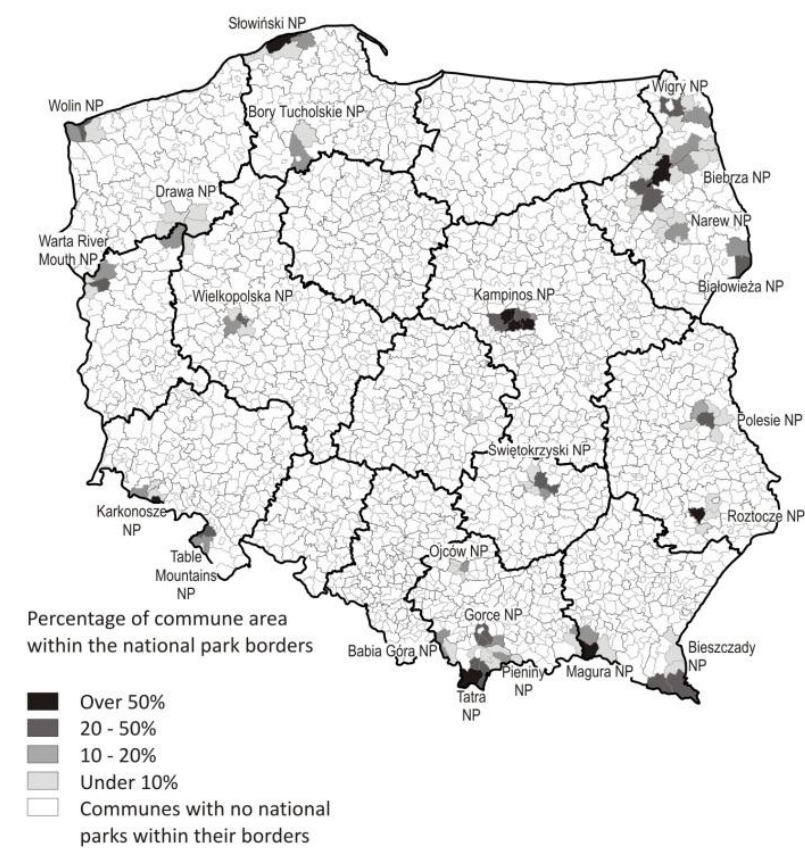

Figure 1. Communes administratively related to national parks in Poland

Source: own study

The questionnaire was sent to municipalities by email in July 2011. The municipalities that did not respond to the survey were contacted by telephone in August and another copy of the survey was sent to them. Some of the municipalities, despite several phone calls, did not respond to the survey. Return questionnaires were obtained at $74 \%$ - from 45 municipalities administratively related with national parks.

The survey questionnaire contained 17 questions, mostly closed questions. Respondents were asked, for example, to asses the importance of particular economy sectors (including tourism) in the socioeconomic development of municipalities, the importance of a national park in the general development of the municipality, as well as the direct and indirect impacts of the operation of the park on various spheres of socio-economic development, the attitude of the authorities and residents to park operation and the relations between local governments and managements of national parks. In open questions, respondents were asked to identify the main benefits and negative effects of the operation of a national park in the municipality, as well as possible privileges which should be granted to the municipalities with a national park within their borders.

\section{Results}

In the municipalities that responded to the survey, tourism is the most important branch of economy. 
$36 \%$ of municipalities rated it is a key function, $29 \%$ of the municipalities listed tourism in the second position. Among other functions, the most important are: agriculture, trade, services (excluding tourismrelated) and forestry. Further growth of tourist function is anticipated - as many as $58 \%$ of respondents believe that tourism will be the key function of the municipality and the main sector of services and trade in the future.

Representatives of $29 \%$ of municipalities declared that the park was of 'significant' importance to the general development of the municipality; in $16 \%$ of municipalities, its importance was described as 'very significant'. Only in $7 \%$ of cases it was considered 'marginal'. The influence of a national park on the socio-economic situation of a commune was assessed as rather positive. Nonetheless, it is worth emphasising that benefits of the functioning of a park are, in respondents' opinion, currently greater than in the past. The growth of benefits is anticipated in the future.

In five-point scale (from -2 to +2 points), the influence of a park on local socio-economic situation was rated at average 0.3 level (o.1- in the past, 0.8 - in the future) - figure 2. A significantly negative influence was not noticed in any municipality. The influence was described as significantly positive in $7 \%$ of communes. In the future, a very positive influence of park's functioning on the socio-economic situation is anticipated by $24 \%$ of respondents, whereas only $11 \%$ believe that the park will continue to have a rather negative influence. According to local officials, the positive aspects of national parks are easier noticeable at the administrative level of the poviats (counties) and voivodeship (provinces). Impact of parks on the socio-economic situation of these areas was rated at average of 3.7 (counties) and 3.9 (provinces).

Benefits resulting from the existence of national parks are noted primarily in the field of tourism. In as many as $44 \%$ of the municipalities, the existence of a park was regarded as significantly positive for development of tourism, in $53 \%$ the influence was rated as rather positive. Parks also positively influence the condition of the natural environment, as well as the ecological awareness of the residents. It is surprising that the positive impact of parks on spatial harmony in municipalities was rated as low (figure 3). Negative aspects of the existence of parks were noticed mainly with regard to the revenues to the municipality's budget. Also, parks have a negative impact on agriculture and fishery development.

In addition to assessing the impact of a park on the above discussed elements, respondents were asked to list the most important advantages and disadvantages of a park in the municipality. In $76 \%$ of responses, tourism (including agritourism) and related services development were mentioned as the main advantage. Additionally, a quarter of respondents noted the park's role in promoting the community. $40 \%$ of responses regarded the positive influence of the park on the condition of the natural environment as one of the most important advantages. Moreover, among the most frequently mentioned positive factors were the environmental education and an increase in the environmental awareness of population, the possibility of living in a clean environment, the development of organic farms. Only one municipality did not find any benefits of the existence of the park.

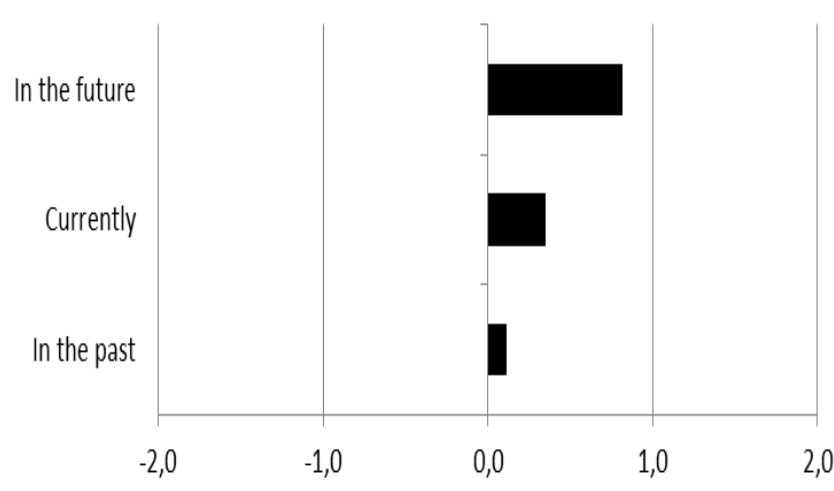

-2 - significantly negative, $-1-$ rather negative, $o-$ neutral, $1-$ rather positive, 2 - significantly positive

Figure 2. The assessment of national parks' influence on the socio-economic situation of the communes.

Source: own study.

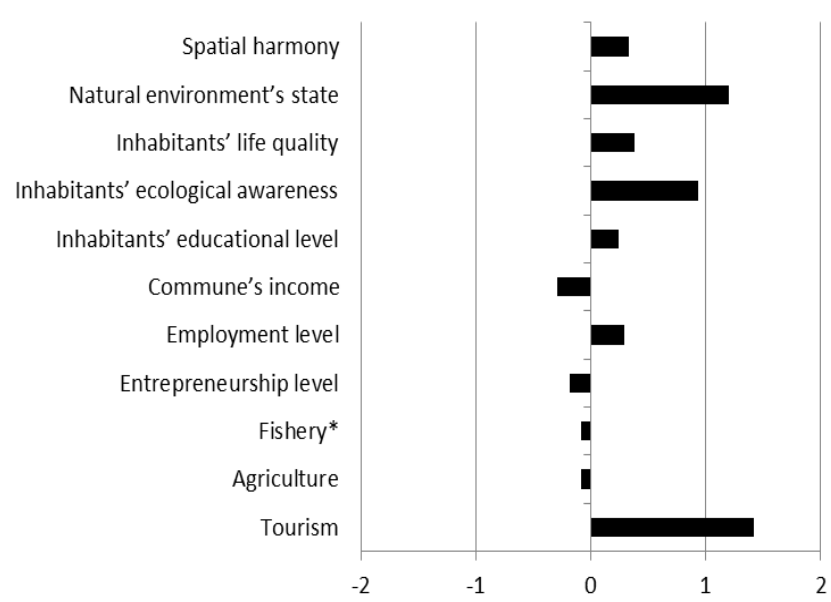

*filled only by communes affected by this issue ( 22 communes altogether)

-2 - significantly negative, -1 - rather negative, $o$ - neutral, 1 - rather positive, 2 - significantly positive

Figure 3. The assessment of influence of national parks' on selected aspects of communes' spatial economy.

Source: own study.

The negative aspects of functioning of a national park within commune borders are associated primarily with restrictions regarding the economic use of the park's area and its buffer zone. The responses most frequently pointed to: investment 
barrier ( $67 \%$ of answers), limiting the development of economic activity (38\%), reduced tax revenues to the budgets of municipalities (16\%), prolonged decisionmaking process due to complex administrative processes and the necessity to assess enterprises, as well as limited access to forests for residents.

Employees of municipal offices that participated in the study all agreed that special privileges should be granted to municipalities with national parks within their borders. However, the answers concerning specific suggestions were very diverse. More than half of municipalities expect financial compensation from the national budget to compensate for the limited socio-economic development opportunities as well as for the lost income. Moreover, most responses presented the opinion that municipalities should be granted subsidies or favourable conditions when applying for grants for investments benefiting the environment (i.e. sewage system extension, building sewage treatment plants, modernizing traditional boiler rooms, thermal insulation of buildings, waste disposal, construction of facilities producing renewable energy), tourism development (including the joint promotion of the community and the park), expansion or upgrading of infrastructure such as tourist trails, didactic paths, roads (for example: building animal passages). Also other detailed suggestions were presented such as, for example, introduction of concession taxes for inhabitants who use ecological energy sources, giving inhabitants the opportunity to use parks' educational offer free of charge.

Attention was also drawn to the issues concerning increasing the influence of local authorities on actions taken in a national park. It has been argued that all major issues concerning the development of the park and its surroundings should be consulted with municipalities; the municipalities should be able to participate in the arrangements, not only to assess the conservation plans for the park; representatives of municipalities should be represented in the board that chooses the director of the national park.

The survey also contained questions about the relationship and the cooperation between local authorities and parks' management. Respondents declare a positive attitude of municipality authorities towards the existence of a national park (average rate 4.o). Only one of the municipalities admitted that the attitude is rather negative. The rate of inhabitants' attitude was slightly lower (average rate 3.2) - figure 4. In $9 \%$ of municipalities, it was admitted that inhabitants have a very negative attitude towards the park, whereas in as many as $29 \%$ the attitude was described as rather negative.

A very positive attitude towards the functioning of a park is presented by authorities of $8 \%$ and inhabitants of $2 \%$ of all municipalities. Municipality authorities also assess former contacts with management of national parks as rather positive (average rate o.7). Only one commune described mutual relations as very negative.

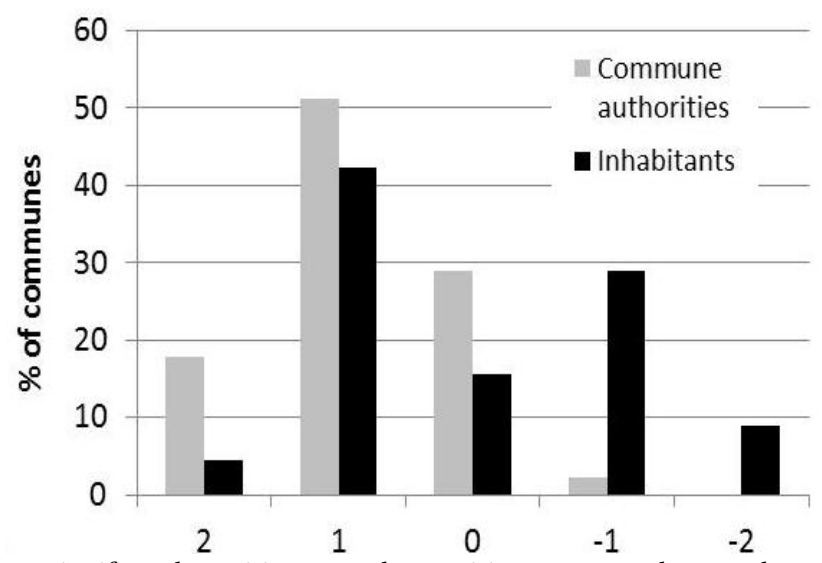
2 - significantly positive, 1 - rather positive, $\mathrm{o}$ - neutral, $-\mathbf{1}$ - rather negative, -2 - significantly negative

Figure 4. The attitude of communes' authorities and its inhabitants to the existence of national parks Source: own study.

Unfortunately, the declared positive attitude of officials to national parks and their managers is not reflected in cooperation. The partnership-based model for joint management of the area by the local council and director of the national park does not function in any municipality. Moreover, continuous contacts and regular cooperation are declared only by $22 \%$ of respondents (in 7 national parks). In most cases, contact between the municipal office and the park management is limited only to the legally required consultation and assessment $(38 \%)$ or occasional consultation concerning particular activities and very rare joint initiatives (27\%) - figure 5 .

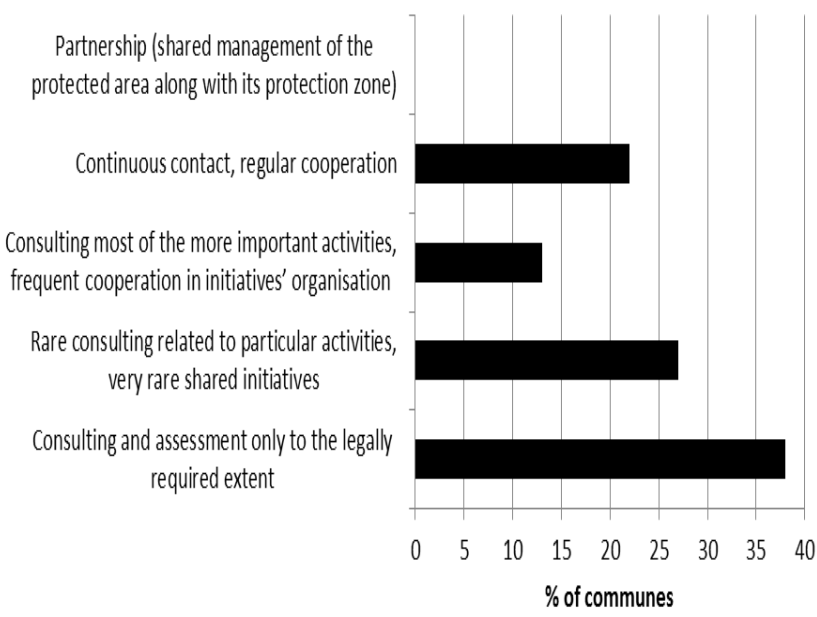

Figure 5. Cooperation between communes and the management bodies of national parks

Source: own study. 
Respondents assess relations with neighbouring municipalities as positive (average rate 4.0). Unfortunately, contacts among neighbouring municipalities are limited to consultations on specific activities or very rare joint initiatives $38 \%$ of answers). In $20 \%$ of communes, it was admitted that rare contacts are only established in case of necessary agreements, and joint initiatives are not taken. Only $18 \%$ of municipalities stated that contacts with neighbouring communes are constant, the cooperation is regular and communes situated in a particular park pursue common development goals. Unfortunately, most of those opinions were not confirmed in neighbouring communes.

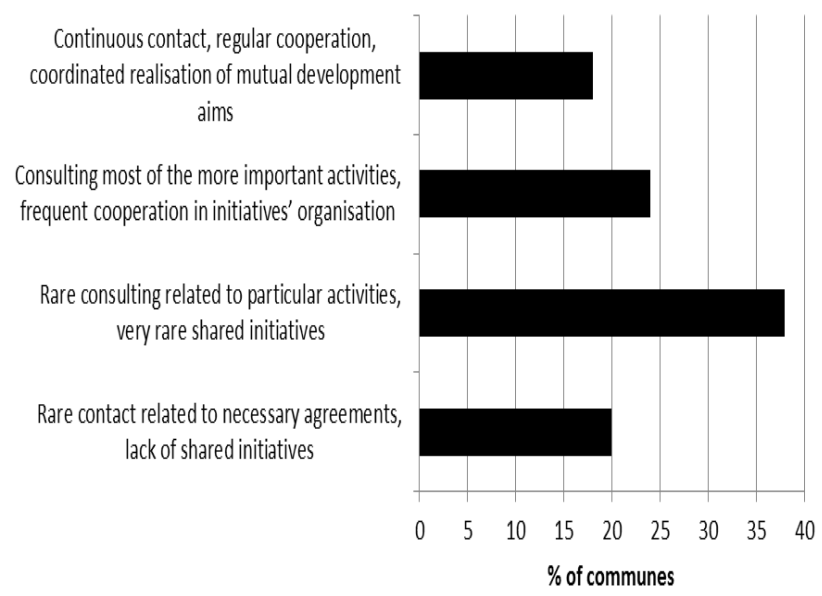

Figure 6. Cooperation among communes situated within a particular national park

Source: own study.

\section{Discussion}

The majority of national parks in Poland were created in years 1950-1990, as a result of centrally-made decisions based on environmental criteria which did not take local community's interests into consideration. Park's protection was applied not only on state owned lands but also on private ones. Even currently $15.9 \%$ of the total area of national parks in Poland is in private hands. Creating a park introduced regulations and restrictions which locally significantly changed economic conditions. High costs bore by local communities led to negative perception of national parks and conflicts.

The view on national parks has changed after 1989, due to economic transition and development of private enterprise, which enables deriving higher income from tourism. Parks are perceived now not only as a guarantee for preservation of natural values, but also as a factor for development of tourism and ecological agriculture. The social awareness of the natural environment's condition for the health also rises. Moreover, pro-ecological investments made in the parks and surrounding areas, as well as activities of educational character increase the public support for protected areas.

Regardless of the positive social tendencies, the negative aspects of the existence of national parks directly related to the economic constraints of land use are still perceptible, especially within the borders of parks and in their immediate vicinity. Answers given by municipalities in the survey pointed out the number of problems associated with the operation of national parks. In local authorities opinions the benefits of parks' functioning are greater in regional scale than on the local level. Similar opinions has been observed in case of national parks in Austria ( $c f$. Getzner, 2003).

Nine of Polish national parks are part of the international network of UNESCO biosphere reserves. According to the network's guidelines, the parks should set a model example of harmonious socio-economic development conforming to the conservation of wildlife, natural and cultural values (UNESCO 1996, Madrid Action Plan for Biosphere Reserves 2008-2013). Except their conservation functions, these reserves should perform the function of development - encouraging forms of economic and human development, which can be regarded as a socio-culturally and ecologically sustainable. They should also support model projects, ecological education and training as well as studies and monitoring concerning local, regional, national and global issues of conservation and sustainable development (Breymeyer, 1997). These goals of biosphere reserves can undoubtedly be extended to all national parks, as exemplified by the operation of parks in France (Finger-Stich, Ghimire, 2000).

Implementation of these objectives is not possible without close cooperation between national parks' management and local authorities. Managing park's areas and individual municipalities with parks within their borders can not be done separately. A holistic view of the park as a system linked to the socioeconomic environment is necessary, as well as creating a management model which allows increasing social participation in the decision-making process, while ensuring high standards of environmental protection. Unfortunately, the recommended cooperation between local authorities and parks' management in planning the development of the park and surrounding areas, as well as implementation of joint projects, cannot be found in Poland. Partnership model (joint management of park and its buffer zone) does not function and the cooperation is occasional. A possible step forward may be the creation of the Polish Association of Local Authorities Cooperating with National Parks in 1999. 
Harmonious development of national parks and their surroundings requires coordination of actions not only between the its management and municipal authorities, but also between municipalities with an administrative connection to the park. Creating strategies (plans) of sustainable development for the entire area of all local government units covered by a particular park is conducive to the integration of communities and implementation of joint development goals (Dąbrowski, 2009). Unfortunately, such solution is not practiced in Poland; planning documents are developed separately for areas within national parks' borders and for particular local government units. Close cooperation of municipalities surrounding national parks is rare. According to the answers given in the survey, a national park does not play a integrative role for the administratively connected municipalities.

The study has shown that the functioning of national parks is of significant importance for the development of most concerned municipalities. The influence of a park on the administrative units depends, to some extend, on the percentage of the area of the municipality that is covered by protection. However, municipalities that responded in the survey did not show a clear correlation between these two traits. Therefore the area of the municipality covered by the park does not determine the park's importance to the local socio-economic system. More important is the system of functional relations between the national park and the local economy. The parks have a positive influence on tourism development and a slight positive effect on the employment level. However, they represent a barrier for the development of agriculture, fishery and local entrepreneurship. Similar results were obtained for Austrian national parks (Getzner, 2003), where the benefits were recognized especially in tourism and agriculture development, as well as the appearance of new investments and enterprises.

The significance of Polish national parks in generating new jobs is observed especially in peripheral areas with high unemployment. In the past 10 years, the population has decreased in half of municipalities administratively linked to national parks, mainly as a result of economic migration. Loss in population occurred primarily in municipalities with national parks located far from major metropolitan centres, i.a.: Karkonosze NP, Bieszczady NP, Polesie NP, Biebrza River NP, Drawa River NP. Conversely, the positive migration balance occurred in municipalities with parks' areas located near big agglomerations (Wielkopolska NP, Kampinos NP, Ojców NP) as well as the Tatra NP, which is mainly determined by suburbanisation processes.

Almost all municipalities recognize the positive influence of a national park on tourist development.
The significant role of tourism in future development is confirmed by the fact that as many as $93 \%$ of local development strategies set goals and objectives in tourism. In many strategies, tourism development was placed among strategic aims. The high attractiveness of the natural and often cultural environment in the studied areas is undoubtedly the basis for the development of tourist functions. However, the peripheral location of some of the national parks and restrictions for development of mass tourism are significant barriers to the development. In this condition, it appears that many of the surveyed municipalities can count on tourism development only as a complementary function and the expected benefits from tourism will not compensate for the losses caused by the regulation or reduction other economic activities.

\section{Conclusions}

National parks are of great meaning to the socioeconomic development of municipalities in Poland. Increasing benefits are noticed especially in the tourism sector as well as in related services. The attitude of local authorities and residents to national parks is diverse, due to the fact that local communities feel many restrictions arising from the operation of protected areas. However, approving attitudes prevail.

In the future, national parks should stimulate local development to a greater extent. Therefore it is necessary to look at as a national park system linked to the socio-economic environment. Moreover, it is necessary to plan activities based on a holistic look at environmental, social and economic issues of a national park and its neighbourhood. For areas where losses outweigh the benefits of the operation of parks, alternative development directives should be developed (for example, alternative forms of tourism, organic farming). Moreover, an compensation possibilities for municipalities and residents should be analyzed.

In order to increase the benefits associated with the existence of national parks, cooperation between municipal offices, the management of parks, nongovernmental organisations and local tourism industry should be tightened. It is also important to develop specialised human resources (both in offices of the municipalities and national parks' management), specializing in particular in spatial planning, tourism and promotion. Moreover, actions to activate residents and to increase in public participation in planning and implementation processes are required. 


\section{References}

Bołtromiuk, A 2010, Ekonomiczny kontekst funkcjonowania Białowieskiego Parku Narodowego i sqsiadujacych gmin (Economic context of operation of the Biatowieski National Park and the adjacent communes), Wieś i Rolnictwo, vol. 3(148), pp. 130-155.

Bołtromiuk, A (ed.) 2001, Gospodarowanie na obszarach chronionych, Wydawnictwo Uniwersytetu w Białymstoku, Białystok.

Borrini-Feyerabend, G, Kothari, A \& Oviedo, G 2004, Indigenous and Local Communities and Protected Areas. Towards Equity and Enhanced Conservation. Guidance on Policy and Practice for Co-managed Protected Areas and Community Conserved Areas, IUCN, Gland, Switzerland and Cambridge, UK.

Breymeyer, A (ed.) 1997, Rezerwaty biosfery w Polsce. Biosphere Reserves in Poland, National UNESCO-MAB Committee of Poland, Warszawa.

Central Statistical Office 2011, Ochrona środowiska 2011 (Environment 2011), Warsaw.

Davey, AG 1998, National System Planning for Protected Areas, IUCN, Gland, Switzerland and Cambridge, UK.

Dąbrowski, P 2009,'Społeczne funkcje rezerwatów biosfery (Social functions of biosphere reserves)', in B Domański \& W Kurek (eds.), Gospodarka i Przestrzeń, Institute of Geography and Spatial Management of the Jagiellonian University, Krakow.

Department of Environment, Climate Change and Water NSW 2009, Economic benefits of national parks and other reserves in New South Wales - Summary report, Sydney.

Dudley, N(ed.) 2008, Guidelines for Applying Protected Area Management Categories, IUCN, Gland, Switzerland.

Finger-Stich, A \& Ghimire, K 200o,'Local development and parks in Francé, in K Ghimire \& M Pimbert (eds.), Social change and conservation, Earthscan, London.

Fortin, MJ \& Gagnon, C 1999,'An assessment of Social Impacts of National Parks on Communities in Quebec', Environmental Conservation, vol 26(3), pp. 200-211.

Getzner, M 2003,'The Economic Impact of National Parks: the Perception of Key Actors in Austrian National Parks', International Journal of Sustainable Development, vol. 6(2), pp. 183-202.

Gorczyca, E \& Krzemień, K 2002,'Wpływ ruchu turystycznego na rzeźbę Tatrzańskiego Parku Narodowego (Impact of tourism on the relief of the Tatra National Park'), in J Pociask-Karteczka, A Matuszyk \& P Skawiński (eds.), Stan i perspektywy rozwoju turystyki w Tatrzańskim Parku Narodowym (State and perspectives of tourism in the Tatra National Park), Academy of Physical Education in Krakow, Tatra National Park, CracowZakopane.

Gotkiewicz, W 2001,'Gospodarstwa rolne w parkach narodowych - szanse i bariery rozwoju', Roczniki Naukowe Stowarzyszenia Ekonomistów Rolnictwa i Agrobiznesu, vol. 3III(6), pp. 90-94.

Hamilton, L \& McMillan, L (eds.) 2004, Guidelines for Planning and Managing Mountain Protected Areas, IUCN, Gland, Switzerland and Cambridge, UK.

Huhtala, M 2007; Assessment of the local economic impacts of national park tourism: the case of PallasOunastunturi National Park, Forest Snow and Landscape Research, vol. 81(1/2), pp. 223-238.
IUCN 1998, Economic values of protected areas. Guidelines for protected area managers, IUCN, Gland, Switzerland and Cambridge, UK.

Jodłowski, M 2011, Zasady dobrej praktyki w zarządzaniu ruchem wspinaczkowym na obszarach chronionych (Goodpractice manual of climbing management in protected areas), Instytut Geografii i Gospodarki Przestrzennej Uniwersytetu Jagiellońskiego, Kraków.

Konopka, M 2001,'Warunki i możliwości rozwoju ludności zamieszkującej na obrzeżach obszarów chronionych (Gmina Podgórzyn)', Prace Naukowe Akademii Ekonomicznej, vol. 905, pp. 293-297.

Łajczak, A, Michalik, S \& Witkowski, Z (eds.) 1995, Wptyw narciarstwa i turystyki pieszej na przyrodę Masywu Pilska (The impact of skiing and hiking on the nature of the Pilsko Massif, Western Carpathians), Studia Naturae 41, Instytut Ochrony Przyrody PAN.

Meyer, M, Müller, M, Woltering, M, Arnegger, J \& Job, H 2010, The economic impact of tourism in six German national parks', Landscape and Urban Planning, vol. 97(2), pp. $73-82$.

Mika, M 2004, Turystyka a przemiany środowiska przyrodniczego Beskidu Śląskiego (Tourism and the environmental change in the Silesian Beskid Mountains), Instytut Geografii i Gospodarki Przestrzennej Uniwersytetu Jagiellońskiego, Kraków.

Mose, I (ed.) 2007, Protected areas and regional development in Europe: towards a new model for the $21^{\text {st }}$ Century, Ashgate Publishing, Aldershot, UK.

Osiniak, T, Poskrobko, B \& Sadowski, A 1993, Wigierski Park Narodowy a jego mieszkańcy, Wydawnictwo Ekonomia i Środowisko, Białystok - Kraków.

Owsiak, J, Sewerniak, J, Andrzejewska, G \& Szwedowska, G 2001, Turystyka na obszarach chronionych jako czynnik rozwoju społeczno-ekonomicznego społeczności lokalnych. Stan i uwarunkowania rozwoju, Instytut Turystyki, Zakład Naukowo-Badawczy w Toruniu, Torun (typescript).

Partyka, J (ed.) 2002, Użytkowanie turystyczne parków narodowych. Ruch turystyczny - zagospodarowanie konflikty - zagrożenia, Instytut Ochrony Przyrody PAN, Ojcowski Park Narodowy, Ojców.

Pawlusiński, R, Mika, M \& Faracik, R 2008, Regional tourism management and development plan in the Babia Gora Region, Projekt UEP-GEF Babia Góra, Kraków.

Pearce, D 1981, Estimating visitor expenditure: A review and New Zealand case study, International Journal of Tourism Management, vol. 2(4), pp. 240-252.

Phillips, A 2002, Management Guidelines for IUCN Category $V$ Protected Areas: Protected Landscapes/Seascapes, IUCN, Gland, Switzerland and Cambridge, UK.

Plummer, R \& Fennell, DA 2009, Managing Protected Areas Form Sustainable Tourism: Prospects for Adaptive Comanagement', Journal of Sustainable Tourism, vol. 17 (2), pp. 149-168.

Popławski, Ł 2005, Bezrobocie na obszarach chronionych w województwie świętokrzyskim', Zeszyty Naukowe Małopolskiej Wyższej Szkoły Ekonomicznej $w$ Tarnowie, vol. 8, pp. 109-122.

Poskrobko, B (ed.) 1996, Rejon Puszczy Białowieskiej. Mieszkańcy - Środowisko - Gospodarka. Studia i Materiały No. 1, Politechnika Białostocka, Katedra Ekonomiki i Zarządzania Ochroną Środowiska, Białystok. 
Ptaszycka-Jackowska, D \& Baranowska-Janota, M 1996, Przyrodnicze obszary chronione. Możliwości użytkowania, Instytut Gospodarki Przestrzennej i Komunalnej, Warszawa.

Reinius, S \& Fredman, P 2007, Protected Areas as Attractions', Annals of Tourism Research, vol. 34(4), pp. 839-854.

Saayman, M \& Saayman, A 2006a,'Estimating the economic contribution of visitor spending in the Kruger National Park to the regional economy', Journal of Sustainable Tourism, vol. 14(1), pp. 67-81.

Saayman, M \& Saayman, A 2006b,'Creating framework to assess the economic contribution of National Parks in South Africa. The case of the Addo Elephant National Park, Tourism Economics, vol. 12(4), pp. 619-633.

Saayman, M, Saayman, A \& Ferreira, M 2009, The socioeconomic impact of the Karoo National Park, Koedoe 51(1), Art. 158, viewed on March ${ }_{11}^{\text {th }}$ 2011, www.koedoe.co.za.

Stolton, S \& Dudley, N (eds.) 2010, Arguments for protected areas. Multiple benefits for conservation and use, Erthscan, London.

Stynes, DJ 2002, Economic impacts of Great Smoky Mountains National Park visitors on the local region, 199720oo, Department of Park, Recreation and Tourism Resources, Michigan State University, Michigan.

Stynes, DJ, Propst, D, Chang, W \& Sun, Y 2000, Estimating National Park visitor spending and economic impacts; The MGM2 Model, Department of Park, Recreation and Tourism Resources, Michigan State University, Michigan.

Stynes, DJ \& Rutz, EA 1995, Regional economic impacts of Mammoth Cave National Park, Department of Park, Recreation and Tourism Resources, Michigan State University, Michigan.
Szczepanowski, A 2007,'Problemy prowadzenia gospodarki turystycznej na obszarach przyrodniczo cennych', in J Wyrzykowski (ed.), Rola turystyki w gospodarce regionu, Wyższa Szkoła Handlowa we Wrocławiu, Wrocław.

Szkiruć, Z 2001,'Społeczne aspekty funkcjonowania Wigierskiego Parku Narodowego', in A Richling \& J Solon (ed.), Struktura i funkcjonowanie Wigierskiego Parku Narodowego, Wydział Geografii i Studiów Regionalnych, Uniwersytet Warszawski, Warszawa.

UNESCO 2008, Madrid Action Plan for Biosphere Reserves (2008-2013), viewed on March $27^{\text {th }}$ 2012, www.unesco.org/mab.

UNESCO 1996, Biosphere reserves: The Seville Strategy and the Statutory Framework of the World Network, Paris.

Zawilińska, B 2010a, Możliwości rozwoju turystyki w parkach krajobrazowych Karpat Polskich w świetle idei zrównoważonego rozwoju, Uniwersytet Ekonomiczny w Krakowie, Kraków.

Zawilińska, B 201ob,'Turystyka przyrodnicza w rozwoju polskich regionów (Nature Tourism In Development of Polish Regions)', in T Kudłacz (ed.), Rozwój regionalny w Polsce w świetle wyzwań XXI w. (Regional Development In Poland In the Light of the XXI Century Challenges), Polska Akademia Nauk, Komitet Przestrzennego Zagospodarowania Kraju, vol. studia CXXXI, pp. 123-135.

Zimniewicz, $\mathrm{K}$ 2005, Zarządzanie polskimi parkami krajobrazowymi. Próba diagnozy, Akademia Ekonomiczna w Poznaniu, Poznań. 